StAmEY, T.A. (1956) The pathogenesis and implications of the electrolyte imbalance in ureterosigmoidostomy. Surgery, Gynaecology and Obstetrics, 103, 736.

STRONG, J.A. (1951) Serum potassium deficiency during treatment with sodium, PAS and liquorice extract. British Medical Journal, 2, 998.

TANNEN, R.L. (1969) The relationship between urinary pH and acid excretion; the influence of urine flow rate. Journal of Laboratory and Clinical Medicine, 74, 757.

TANNEN, R.S. (1970) The effect of uncomplicated potassium depletion in urine acidification. The Journal of Clinical Investigation, 49, 813.

Thomas, P.K. (1968) Diseases of muscles. In: Recent Advances in Medicine (Ed. by D. M. Baron, N. Compston \& A. M. Dawson), 15th edn, p. 46. Churchill, London.
DE WARDENER, H.E. \& HeRXHeImer, A. (1957) Effect of high water intake on kidneys' ability to concentrate urine. Journal of Physiology, 139, 42.

WArren, K.S., Iber, E.L., Dolle, W. \& Sherlock, S. (1960) Effect of alterations in blood $\mathrm{pH}$ on distribution of ammonia from blood to cerebrospinal fluid in patients in hepatic coma. Journal of Laboratory and Clinical Medicine, $56,687$.

Welt, L.G., Hollander, W., Jr, \& Blythe, W.B. (1960) The consequences of potassium depletion. Journal of Chronic Diseases, 11, 213.

Wrong, O. \& Davies, H.E.F. (1959) The excretion of acid in renal disease. Quarterly Journal of Medicine, 28, 259.

\title{
Hypokalaemic myopathy and myoglobinuria due to carbenoxolone sodium*
}

\author{
P. C. BARNES \\ M.B., Ch.B.
}

\author{
J. H. C. LeONARD \\ M.D., F.R.C.P.
}

\section{University Hospital of South Manchester}

IN recent years it has become clear that the use of carbenoxolone sodium (Biogastrone, Duogastrone) may be accompanied by marked hypokalaemia (Turpie \& Thomson, 1965) in addition to retention of sodium, oedema and hypertension. Occasionally the depletion of potassium may be so severe as to cause muscular weakness (Mohamed, Chapman \& Crooks, 1966; Forshaw, 1969; Muir, Laithwaite \& Wood, 1969; Swallow, 1969; Fyfe, Cochran \& Begg, 1969). The patient described by Mohamed et al. also had myoglobinuria. So far as we can determine, the following patient is only the second example in which myoglobinuria has been confirmed following the use of carbenoxolone sodium.

\section{Case report}

A man, aged 75 years, was referred to the outpatient clinic on 23 July, 1969. He had previously been seen in 1962, at which time he had had intermittent abdominal pain for 20 years. A barium meal was normal in 1962, and again in 1966, and a barium enema was also normal in 1966. In January 1969, he lost his appetite and was given mist. mag. trisil. His dyspepsia persisted, and from the middle of May onwards his general practitioner gave him Biogastrone $50 \mathrm{mg}$ t.d.s. Six weeks later, he noticed pain in the back of both lower limbs, tiredness, and generalized muscular weakness. These symptoms became steadily more severe, and 1 week before he was seen he noticed that his urine was becoming dark.

* Request for reprints: University Hospital of South Manchester, Withington, Manchester, 20.
On examination, he looked unwell. The pulse rate was $60 / \mathrm{min}$, with long periods of coupled beats. The jugular venous pressure was normal, but there was moderate ankle oedema. The blood pressure was $170 / 100 \mathrm{mmHg}$. The heart sounds were normal. No abnormalities were noted in the lungs or abdomen. The upper limbs were normal. There was moderate weakness of the trunk muscles, and considerable weakness of the proximal muscle groups of both lower limbs; distally, the power was normal. All the tendon reflexes were virtually absent.

Investigations. The serum electrolytes are recorded in Table 1. The serum aldolase was 68 units $/ \mathrm{ml}$ (normal 3-12 units/ml) and the creatine phosphokinase was 310 units $/ \mathrm{ml}$ (normal 0-12 units $/ \mathrm{ml}$ ). The serum aspartate transaminase was 520 units $/ \mathrm{ml}$ and the serum alanine transaminase was 115 units $/ \mathrm{ml}$. Spectroscopy of the urine showed the presence of myoglobin. A 24-hr specimen of urine contained $0.66 \mathrm{~g}$ of creatinine and $46 \mathrm{mg}$ of creatine (within the normal range). The serum calcium was $8 \cdot 3 \mathrm{mg} / 100$ $\mathrm{ml}$, the serum inorganic phosphorus was $3.2 \mathrm{mg} / 100$ $\mathrm{ml}$, and the serum alkaline phosphatase was $15.5 \mathrm{KA}$ units. The electrocardiogram showed marked ST-T slurring characteristic of hypokalaemia. A muscle biopsy was reported as follows: 'The striated muscle shows focal areas of acidophilic muscle fibres surrounded by small collections of histiocytes. A few basophilic regenerating fibres are present. The blood vessels are normal. The appearances are those of a myopathy of metabolic or "steroid-induced" type' (Dr R. S. Whittaker). Electromyography was 
TABLE 1 .

\begin{tabular}{lccccc}
\hline Date & $\begin{array}{c}\text { Serum } \\
\text { sodium } \\
(\mathrm{mEq} / \mathrm{l})\end{array}$ & $\begin{array}{c}\text { Serum } \\
\text { potassium } \\
(\mathrm{mEq} / \mathrm{l})\end{array}$ & $\begin{array}{c}\text { Serum } \\
\text { chloride } \\
(\mathrm{mEq} / \mathrm{l})\end{array}$ & $\begin{array}{c}\text { Serum } \\
\text { bicarbonate } \\
(\mathrm{mEq} / \mathrm{l})\end{array}$ & $\begin{array}{c}\text { Blood } \\
\text { urea } \\
(\mathrm{mg} / \mathbf{1 0 0} \mathrm{ml})\end{array}$ \\
\hline 23 July & 143 & 1.90 & $80 \cdot 0$ & $45 \cdot 0$ & 48 \\
24 July & 143 & $1 \cdot 50$ & $82 \cdot 0$ & - & 36 \\
25 July & 138 & $2 \cdot 84$ & $92 \cdot 0$ & 30 & 43 \\
26 July & 150 & $2 \cdot 60$ & $97 \cdot 5$ & 30 & 45 \\
27 July & 143 & 3.90 & $100 \cdot 0$ & $33 \cdot 5$ & 60 \\
14 August & 140 & $4 \cdot 30$ & $92 \cdot 5$ & & \\
\hline
\end{tabular}

reported as follows: 'Right anterior deltoid, fibrillation + , positive sharp waves, complete pattern, 1.25 millivolts (mV) amplitude; right middle deltoid, irritable, no spontaneous activity, complete pattern, $1.5 \mathrm{mV}$, a few broken units; right biceps, fibrillation + , positive sharp waves, complete pattern, $1.25 \mathrm{mV}$, short duration units + ; right iliopsoas, fibrillation ++ , complete pattern, $1.75 \mathrm{mV}$, highly polyphasic; left anterior deltoid, fibrillation ++ , complete pattern, $0.75 \mathrm{mV}$, short duration units ++ . These findings are entirely consistent with a diagnosis of polymyositis' (Dr E. P. Copp).

Treatment with Biogastrone was discontinued, and the patient was admitted to hospital and given large amounts of potassium orally and intravenously. He rapidly improved and ultimately made a complete recovery. When seen as an out-patient on 24 September, muscle power had returned to normal, and his electrocardiogram was also normal.

\section{Discussion}

It is apparent that this man had widespread muscular necrosis, as demonstrated by the high levels of serum enzymes, the muscle biopsy, electromyography, and the appearance of myoglobin in the urine. This is presumably due to the profound hypokalaemia induced by the carbenoxolone sodium. Hypokalaemic myopathy has also been reported following the ingestion of liquorice (Gross, Dexter \& Roth, 1966; Holmes et al., 1970) and in the patient described by Gross et al. (1966) myoglobin was found in the urine. Carbenoxolone sodium is related to glycyrrhetinic acid and hence to liquorice, and Holmes et al. (1970) have produced evidence of low levels of renin and aldosterone in the plasma of their patient who was an habitual consumer of large amounts of liquorice. It seems very likely that a similar mechanism operates in some patients treated with carbenoxolone sodium.

\section{References}

Forshaw, J. (1969) Muscle paresis and hypokalaemia after treatment with Duogastrone. British Medical Journal, 2, $\vec{\omega}$ 674.

Fyfe, T., Cochran, K.M. \& BegG, T.B. (1969) Myopathp and hypokalaemia in carbenoxolone therapy. Britis Medical Journal, 3, 476.

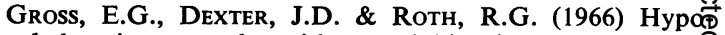
kalaemic myopathy with myoglobinuria associated witR licorice ingestion. New England Journal of Medicine, 27 602.

Holmes, A.M., Marrott, P.K., Young, J. \& Prentice, (1970) Pseudohyperaldosteronism induced by habitua ingestion of liquorice. Postgraduate Medical Journal, 46 625.

Mohamed, S.D., Chapman, R.S. \& Crooks, J. (1966) Hypokalaemia, flaccid quadriparesis, and myoglobinuria with carbenoxolone (Biogastrone). British Medical Journal, $1,1581$.

Muir, A., Laithwaite, J.A. \& Wood, W. (1969) Hypokalaemia complicating carbenoxolone (Duogastrone) therapy. British Medical Journal, 2, 512.

Swallow, M. (1969) Hypokalaemia after treatment with Duogastrone (carbenoxolone). British Medical Journal, 3, 238.

TurPie, A.G.G. \& Thomson, T.J. (1965) Carbenoxolone sodium in the treatment of gastric ulcer with special reference to side-effects. Gut, 6, 591 . 